\section{Kingella kingae}

\author{
Ingrid Araya D. y Rossanna Camponovo C.
}

\section{Generalidades}

En 1976 Moraxella kingae fue transferida al nuevo genero Kingella que pertenece a la familia Neisseriaceae.

El género Kingella tiene 3 especies: K. kingae, que coloniza el tracto respiratorio superior, principalmente en niños, $K$. oralis, que se encuentra en la cavidad oral y $K$. denitrificans cuyo hábitat es desconocido.

$K$. kingae era descrita como una rara causa de infección en humanos, sin embargo en la última década han aumentado los reportes, probablemente por una mejor recuperación e identificación, teniendo predilección por lactantes y niños menores en quienes produce fundamentalmente infecciones osteoarticulares. También es causa de endocarditis (formando parte del grupo HACEK), septicemia, queratitis e infección del SNC.

\section{Características microscópicas}

Bacilos Gram negativos cortos con extremos rectos, no posee flagelos, puede agruparse en pares o cadenas. En ocasiones puede resistir la decoloración de la tinción de Gram, pudiendo ser confundido con bacilos Gram positivos.

La tinción de Gram del líquido articular puede ser negativa, lo que no descarta su presencia.

\section{Características fisiológicas y macroscópicas}

Anaerobio facultativo, nutricionalmente fastidioso, de lento crecimiento, se desarrolla en agar sangre, chocolate o medios líquidos suplementados.

Produce colonias de 1 a $2 \mathrm{~mm}$ de diámetro a las 48 horas, mucosas con una papila central, pueden presentar bordes irregulares. Presenta un pequeño halo de $\beta$ hemólisis en agar sangre de cordero.

\section{Identificación bacteriana}

Se debe sospechar frente a un bacilo gramnegativo que se desarrolla en agar chocolate y sangre, pero no en agar MacConkey, oxidasa positivo, catalasa y nitrito negativo.
Las pruebas adicionales para completar su identificación son:

- Producción de ácido a partir de glucosa y maltosa, y negativo para lactosa, sacarosa, xilosa y manitol.

- Fosfatasa alcalina positiva, ureasa e indol negativo.

(El API NH bioMerieux ${ }^{\circledR}$, es útil para realizar varias de estas pruebas identificatorias)

El empleo de botellas de hemocultivos para inocular el líquido articular ha permitido la mayor recuperación de K. kingae en comparación a la siembra directa en medios sólidos.

\section{Tratamiento}

Penicilinas y cefalosporinas son los antimicrobianos de elección, en forma excepcional se ha descrito cepas productoras de $\beta$ lactamasa. También es susceptible in vitro a macrólidos, quinolonas, aminoglicósidos y tetraciclinas.

La CLSI (ex-NCCLS) no ha estandarizado el estudio de susceptibilidad a antimicrobianos para este microorganismo.

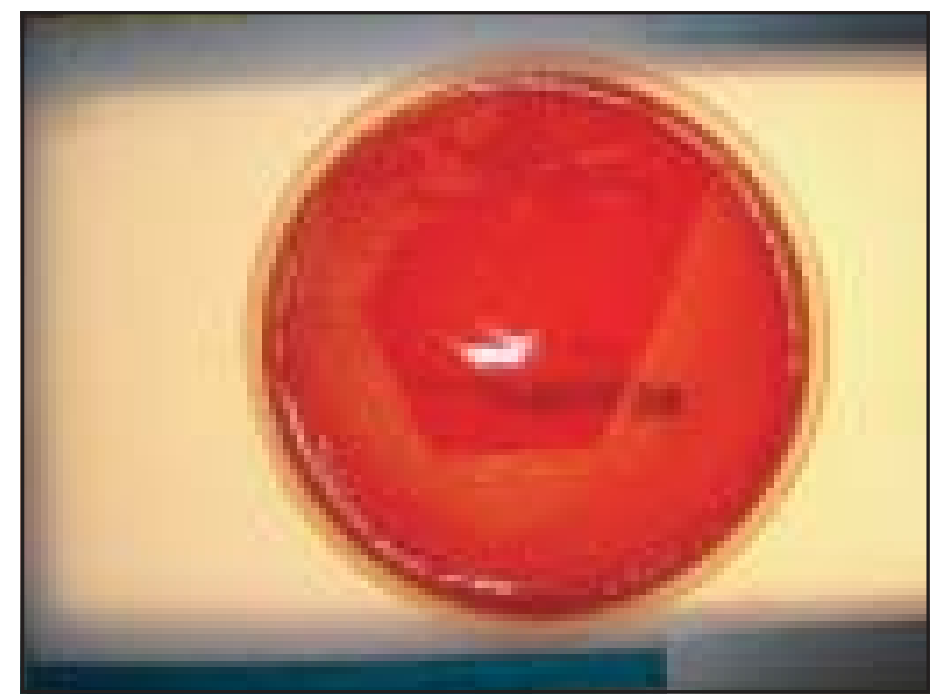

Figura 1. Cultivo de $K$. kingae en agar sangre de cordero. Se aprecia colonia mucosa y $\beta$ hemólisis.

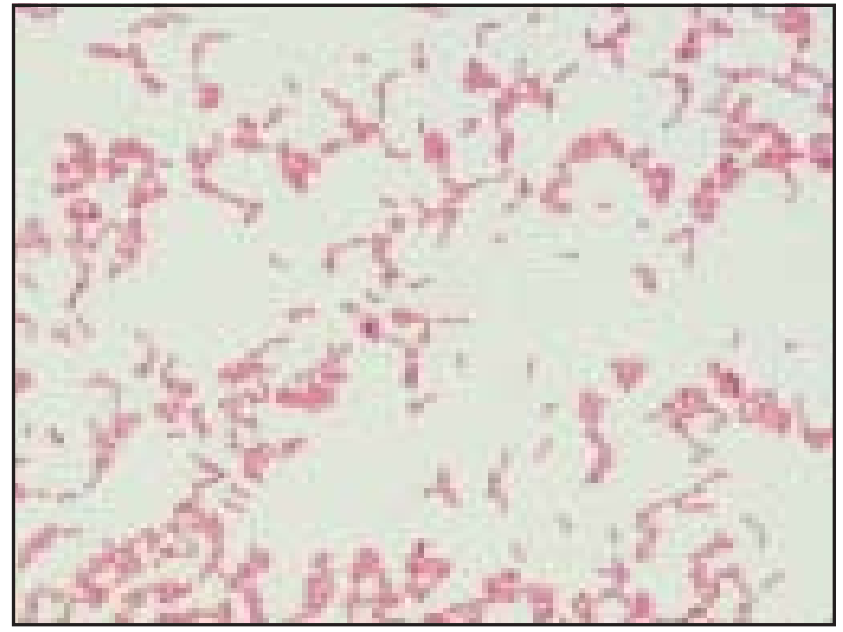

Figura 2. Gram de una colonia de $K$. kingae. Se aprecian bacilos gramnegativos cortos con extremos rectos agrupados en pares y cadenas. 